\title{
Single-Screw Laboratory Extruder for Production of Expanded Products: Design, Construction and Performance Testing
}

\author{
Adekanmi Olusegun Abioye ${ }^{1}$, John Oluranti Olajide ${ }^{1}$ and Patrick Obi Ngoddy ${ }^{2}$ \\ 1. Department of Food Engineering, Ladoke Akintola University of Technology, P.M.B. 4000, Ogbomoso210222, Nigeria \\ 2. Department of Food Science and Technology, University of Nigeria, P.O. Box 551, Nsukka 410001, Nigeria
}

\begin{abstract}
In this study, a low-capacity single-screw cooking extruder for the manufacture of expanded snacks was designed based on theoretical models and guided operating data and practices of existing cooking extruders. Construction was carried out using locally available engineering materials in modest machine shops satisfying sanitary design criteria and tested using blends of cassava and defatted soybean flour. The extruder developed has throughput, screw speed, barrel diameter, length-to-diameter ratio and power requirement of $13.0 \mathrm{~kg} / \mathrm{h}, 200 \mathrm{rpm}, 40 \mathrm{~mm}, 12$ and $1.908 \mathrm{~kW}$, respectively. The cost of the extruder developed was estimated $¥ 650,000$ in 2016. Extrudates had expansion ratio and trypsin inhibitor reduction which ranged from 1.82 to 2.98 and $61.07 \%$ to $87.93 \%$, respectively, across all treatments. This study demonstrates that a low-capacity and affordable experimental single-screw extruder can be designed and built domestically which can be scaled-up for pilot and industrial applications for the production of expanded snacks.
\end{abstract}

Key words: Single-screw extruder, cassava/soybean blends, expansion ratio, machine throughput, trypsin inhibitor reduction.

\section{Introduction}

Extrusion cooking is a continuous, high temperature, short time (HTST) process which has become a popular, efficient and economical process for the manufacture of convenience foods of diverse textural and functional characteristics such as snacks, ready-to-eat cereals and instant flours [1]. It is a process that combines several unit operations including mixing, cooking, kneading, shearing, shaping and forming [2], and therefore, removes drudgery involved in the traditional preparation of these foods. "Kokoro", "kunnunzaki", "massa" and "fura" are a few examples of a generation of Nigerian snack foods that hold a key to rapid innovation and creativity in ingredient formulation for nutritional enhancement and technological advancement through the application of extrusion cooking technology.

Corresponding author: Adekanmi Olusegun Abioye, Ph.D., research fields: food engineering, food extrusion, thermal processing.
Several works have been done to develop highly nutritious convenience products from vast numbers of food bio-resources available in Nigeria [3-9], but little or no attention has been paid to local development of extruders with which experimental works could be performed. This had really overworked, to the best of the knowledge of the authors, the only Brabender single-screw laboratory extruder (DCE 330, New Jersey, USA) available at the Federal Polytechnic, Mubi, Nigeria. In addition, in spite of the numerous merits of extrusion technology such as its ability to handle various food ingredients, reduced processing costs, enhanced productivity, improved product quality and absence of process effluents [2, 10], the major factor militating against its wider use by local food processors in developing countries (DCs) is the high cost of importation of extruders.

This dearth of laboratory and probably pilot and industrial scale extruders has really hindered the snack and allied industries in Nigeria and other DCs of the world. Only a few industrial units and institutions can 
produce extruded instant flours and snacks on a large scale mainly in response to the need of international or non-governmental organizations for emergency supplies. The main reason for this is that most of these extruders are designed for large-scale operations and require very high investment and technical know-how [11].

The need has long been underscored for simpler, smaller and yet more versatile machines at more affordable prices which are capable of utilizing the vast number of natural food resources [12] in a country such as Nigeria. These include cereal crops such as rice, millet, maize and sorghum; roots and tubers such as cassava, yam, potatoes etc. and a wide variety of legumes rich in proteins and tasty additives such as fruits, vegetables and spices.

Extruder, either single- or twin-screw, thermo-mechanically cooks and texurizes food material and thereby facilitates many chemical and structural transformations. These changes include conversion (gelatinisation) of starch, denaturation and cross-linking of proteins, complex transformation of lipids, stretching or restructuring of tractile components and degradation of vitamins and anti-nutritional factors in legumes, colour development and other changes $[1,13]$. Consequently, these results in products that are in a dry state with typical low water activity $\left(a_{w}\right)$ that require no refrigeration storage [14]. Such products are suitable for DCs where infrastructure for a cold supply chain is inadequate [3].

Despite the advantages of twin-screw over single-screw extruders as thoroughly compared by several investigators [15], the latter is still considered to be more relevant for DCs based on the premises that the capital investment, maintenance and energy cost of a single-screw extruder are generally cheaper than the twin screw type owing to their simpler construction and can easily be fabricated in any local machine/metal workshop in DCs [16]. This study aimed to design and construct a laboratory single-screw extruder, and evaluate its ability to produce expanded products from locally available agricultural raw materials using cassava and soybean flour blends as representative test materials.

\section{Methodology}

\subsection{Design Considerations}

The laboratory-scale single-screw extruder was designed and constructed from locally available engineering materials at low cost that will be compatible with local food processors budgets. The food contacting surface was made in stainless steel to allow for easy cleaning to prevent corrosion and contamination to meet sanitary design requirements. The components were easy to assemble, dismantle and the parts are easily replaced in case of wear and/or damage. The equipment can later be scaled-up to meet the needs of pilot and/or small-scale industrial applications.

\subsection{Design Approach}

The approach adopted for the food extruder design is based on models of the flow rate and energy written for the metering section (Fig. 1) of a plastic (polymer) extruder [17-19] because of similarities to food (biopolymers). In addition, the operating data of existing extruders of different functionalities (shear rates) as profiled in Table 1 compiled by Hauck [20] and Rossen and Miller [21] were used to configure the dimensions of the extruder. This approach was reckoned to be more appropriate because there is dearth of workable equipment with which exploratory trials can be performed to model the extruder.

\subsection{Design Calculations}

In the design process, the capacity, shear rate expected of cooking, the level of pressure likely to be developed within the extruder barrel and rheological characteristics of the food melt are the most paramount parameters as they determine the sizes and dimensions of all the important components of the 
extruder such as screw, shaft diameter, barrel, die, bearings and power requirement of the extruder.

2.3.1 Dimensioning the Screw and Barrel of the Extruder

The barrel diameter (D), flight height $(\mathrm{H})$, length-to-diameter ratio $(\mathrm{L} / \mathrm{D})$ and screw speed $(\mathrm{N})$ were selected as $40 \mathrm{~mm}, 3 \mathrm{~mm}, 12$ and $200 \mathrm{rpm}$, respectively, according to Table 1 (Fig. 1) to exude medium-to-high shear rate $(\gamma)$ conditions expressed by Harper [10] as $\gamma=\pi D N / H$.

Since the object of this work was to design a laboratory cooking extruder, a reasonable small screw pitch $(\ell)$ was selected compared to the diameter of the screw with medium value of helix angles $\left(20^{\circ}\right)$ for which curvature parameters are available in the literature [10] and crew speed that will ensure fairly long residence time (RT) of material, high degree of mixing and uniformity of heat distribution in the channel width (W).

Flight tip width $(b)$ for a single-screw extruder is given by Dziezak [22] to range from $D(0.08)$ to $D$ $(0.12)=3.2-4.8 \mathrm{~mm}$. Any value within or around this range $(5 \mathrm{~mm})$ ascertains enough surface area of shear between the screw flight tips and the barrel for cooking that will not draw much motor power. As a result, screw pitch, channel width (W) and screw length of 30,25 and $485 \mathrm{~mm}$, respectively, were arrived at.

The compression ratio (CR) of the screw is one of the most important criteria defining the type (either cooking or forming) of an extruder. It is the ratio of volume of material displaced per revolution of the shaft

Table 1 Typical operating data for different types of extruder.

\begin{tabular}{llll}
\hline Parameters & Low shear & Medium shear & High shear \\
\hline Feed moisture $(\mathrm{FM})(\%)$ & $25-75$ & $15-30$ & $5-15$ \\
Product density $\left(\mathrm{kg} / \mathrm{m}^{3}\right)$ & $320-800$ & $160-500$ & $32-160$ \\
Maximum barrel temperature $(\mathrm{BT})\left({ }^{\circ} \mathrm{C}\right)$ & $20-65$ & $55-145$ & $110-180$ \\
Maximum product temperature $(\mathrm{PT})\left({ }^{\circ} \mathrm{C}\right)$ & 52 & 79 & 149 \\
Maximum barrel pressure $(\mathrm{MPa})$ & $0.6-6.2$ & $2.0-4.0$ & $4.0-20.0$ \\
Screw speed $(\mathrm{N})(\mathrm{rpm})$ & $30-100$ & $100-200$ & $300-450$ \\
Shear rate $(/ \mathrm{s})$ & 9.5 & $22-47$ & 165 \\
Barrel diameter-to-flight height $(\mathrm{D} / \mathrm{H})$ & $7-15$ & $5-9$ & $7-9$ \\
Barrel length-to-diameter ratio $(\mathrm{L} / \mathrm{D})$ & $5-22$ & $10-25$ & $2-15$ \\
Mechanical energy input into product $(\mathrm{kJ} \cdot \mathrm{h} / \mathrm{kg})$ & $0.01-0.04$ & $0.02-0.08$ & $0.1-0.16$ \\
\hline
\end{tabular}

Source: Hauck [20]; Rossen and Miller [21].

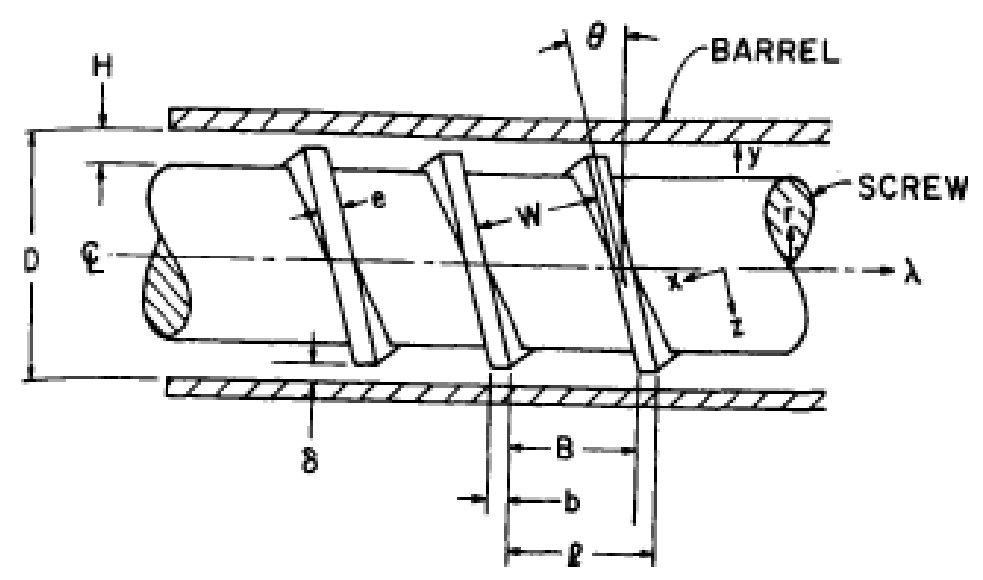

Fig. 1 Geometry of an extrusion screw [10]. 
at the feed section to the volume displaced at the compression section. In practice, CRs for extruder fall between 1 and 5 depending on the level of shear in extruders [10]. For cooking or autogenous extruders, $\mathrm{CR}$ higher than 1 is all that necessary, CR of approximately 2.35 was arrived at as estimated by Singh and Bargale [23] by carefully working on the geometry of the screw so that there would be reasonable cooking of material which will be complemented by heat transferred through the barrel from two electric band heaters of $1 \mathrm{~kW}$ each. Higher CR was avoided in order to prevent excessive viscous dissipation of mechanical energy to the material which will ultimately lead to uncontrollable temperature of the dough in the extruder and consequently, excessive motor power requirements.

In order to achieve compression by the screw, the option of tapered root diameter from $20 \mathrm{~mm}$ at the end of feeding section to $33 \mathrm{~mm}$ at the beginning of the metering section with constant outer diameter of 39 $\mathrm{mm}$ and pitch of $30 \mathrm{~mm}$ was considered. This was chosen as not all the possibilities as elucidated by Harper [10] can be applied in a typical DCs' machine including Nigeria where there is low level of sophistication. The feeding, compression and metering sections are 143, 225 and $135 \mathrm{~mm}$ in length, respectively.

The barrel of an extruder is a thick cylinder made of stainless steel. For thick wall design, maximum tangential stress $\left(\sigma_{\max }\right)$ at the inner surface of barrel is expressed as [24]:

$$
\sigma_{\max }=P\left(\frac{R_{o}^{2}+R_{i}^{2}}{R_{o}^{2}-R_{i}^{2}}\right)
$$

where, $\sigma_{\max }=120 \mathrm{MPa}$ was assumed for cold drawn steel [24], $R_{o}=$ outside radius of the barrel (m), $R_{i}=$ inside radius of the barrel $=20 \mathrm{~mm}$. Hardened stainless steel 431 heat treatable cylinder was selected for the barrel in order to resist both wear and corrosion.

\subsubsection{Capacity of the Extruder}

The resultant volumetric flow rate $(Q)$ of the screw length $[10,25]$ with modifications by Janssen and
Moscicki [26] accounting for shape correction factors of the curvature ends for drag and pressure flows is:

$$
\begin{gathered}
Q=\frac{1}{2} \pi^{2} N D^{2} H \sin \theta \cos \theta\left(1-0.57 \frac{H}{W}\right)-\frac{1}{12} \frac{\pi D H^{3} \Delta P}{\mu L_{s}} \sin ^{2} \theta \\
\left(1-0.62 \frac{H}{W}\right)
\end{gathered}
$$

where, $H, \mu$ and $\Delta P$ are $H(\mathrm{~m})$, viscosity (Pa.s), and pressure $(\mathrm{Pa})$ developed in the extruder die. However, Eqs. (3) and (5) were derived for Newtonian liquids, but food melts are non-Newtonian (pseudoplastic) liquids at extrusion temperatures. Therefore, the viscosity $(\mu)$ parameter in the equations was replaced by an apparent viscosity $(\eta)$ term. The apparent viscosity model of corn and soybean mixture melt (likely feed ingredients to be extruded) published by Fraiha et al. [27] (a form of power law equation for pseudoplastic fluid) is:

$$
\eta=18770(\gamma)^{-0.86} e^{(-934 U+935 T)}
$$

where the influence of shear rate is represented by the power law model, $U$ is the material moisture (percentage) and $T$ is the inverse testing temperature, in Kelvin scale. From the calculation, the machine is capable of producing $13 \mathrm{~kg}$ of the expanded extrudates considering the product density of $150 \mathrm{~kg} / \mathrm{m}^{3}$ (Table 1) having estimated $\eta$ to be $2,442 \mathrm{~Pa} \cdot \mathrm{s}$.

\subsubsection{Power Requirements and Transmission}

In screw extruders, power is required primarily to turn the feed ingredients in melts by viscous mechanical dissipation in the channel, between the screw tips and the barrel and overcome the pressure at the die. All these were accounted for in the power equation developed in plastics extrusion for the same reason as discussed above. The power required is expressed as [10, 25]:

$$
\begin{gathered}
Q=\frac{p(\pi N D)^{2} L_{s}}{\sin \theta}\left(\eta \frac{\mathrm{w}}{\mathrm{H}}\left(\cos ^{2} \theta+4 \sin ^{2} \theta\right)+\eta_{\delta} \frac{e}{\delta}\right)+ \\
\frac{\pi^{2}}{2} D^{2} H\left(1-\frac{p e}{\pi D \sin \theta}\right) \sin \theta \cos \theta N \Delta P
\end{gathered}
$$

where $p, \delta(\mathrm{m})$ and $\eta_{\delta}(\mathrm{Pa} \cdot \mathrm{s})$ are numbers of parallel channels, clearance between the flight tips and barrel (m) and apparent viscosity in the clearance but with $\gamma_{\delta}$, 
shear rate in the clearance which in turn was estimated from Eq. (1) but $H$ was replaced by $\delta$.

The estimated power and specific mechanical energy (SME) values of $1,908.4 \mathrm{~kW}$ and 0.15 $\mathrm{kW} \cdot \mathrm{h} / \mathrm{kg}$, respectively, were in range of operating data values for typical high-shear extruders of 0.16 $\mathrm{kW} \cdot \mathrm{h} / \mathrm{kg}$ as shown in Table 2. This estimated theoretical SME gives credence to the design procedure. Thus, $4 \mathrm{~kW}$, 3-phase AC geared reduction motor (3:1) selected will adequately supply this power to rotate the screw at a speed range of $0-200 \mathrm{rpm}$ controlled by $50 \mathrm{~Hz}$ frequency inverter and transmitted through a coupling plus all additional power required to overcome frictional losses.

\subsubsection{Die Design}

Die design consists of determining the diameter and length of die (hole) to achieve the required product at a given flow rate, $Q$. The radius of the die $\left(R_{d}\right)$ of the die opening was estimated from the relationship between shear rate in the extruder and the volumetric flow rate [28] as:

$$
\gamma_{w}=\frac{3 n+1}{4 n}\left(\frac{4 Q}{\pi R_{d}^{3}}\right)
$$

where $\gamma_{w}$ and $n$ are shear rate (/s) at the wall (taken as $\left.\gamma_{\delta}\right)$ and power index (0.16), respectively, according to Fraiha et al. [27]. This equation implies that expansion will not be achieved above a die diameter (DD) of $8.9 \mathrm{~mm}$. In order to achieve expansion, seven die configurations of lower dimensions with their corresponding lengths were made to suit the objective of a laboratory extruder. Chinnaswamy and Hanna [29] investigated the effect of die opening configurations on the expansion properties of corn extrudates and concluded that ratio of the die opening land to diameter $(L / D)$ of not more than 3.4 increases expansion ratio (ER) of corn extrudates beyond which expansion diminishes. $L / D=3$ of the die opening was thus chosen. For smooth flow of melt from the screw end to the die, the die assembly was machined in the shape of a cone to fit the pointed end of the screw as shown in Fig. 2. The die was circular in shape and made so that it can be externally screwed to the die assembly [16].

\subsubsection{Shaft Design}

Maximum shear stress theory was assumed in determining the stress that can be induced in a $30 \mathrm{~mm}$ diameter mild steel rod that receives the screw in a slotted hole with keyway and a pin to hold the screw in place. In maximum shear theory, axial load developed at the die was accounted for by combining it with the bending moments as [24]:

$$
\frac{\pi}{16} \times \tau_{\max } \times d^{3}=\sqrt{\left(K_{m} \times M+\frac{F_{a} d}{8}\right)^{2}+\left(K_{t} \times T\right)^{2}}
$$

where $\tau_{\max }=$ maximum shear stress induced in the shaft $\left(\mathrm{N} / \mathrm{m}^{2}\right), d=$ diameter of the shaft $(\mathrm{m}), F_{a}=$ axial force, $K_{m}$ and $K_{t}$ are shock and fatigue factors applied to bending and twisting moment, respectively, $M=$ bending moment $(\mathrm{Nm}), T=$ twisting moment $(\mathrm{Nm})$. Since $42.55 \mathrm{MN} / \mathrm{m}^{2}$ is less than the maximum allowable stress in the shaft with keyway and 2.5 assumed as factor of safety, i.e., $56 \mathrm{MN} / \mathrm{m}^{2}$ [30] assuming a gradually loaded condition, i.e., $K_{m}$ and $K_{t}$ of 1.5 and 1 , respectively, and twist of only $0.003 \% \mathrm{~m}$ $(<1 \% \mathrm{~m})$ induced in the shaft, hence the shaft of 30 $\mathrm{mm}$ is considered safe.

\subsubsection{Bearing Design}

The shaft which was connected to a geared motor by way of coupling was supported by two bearings (Fig. 2). One radial ball bearing and one taper roller (thrust) bearing which was forced onto the shaft possess the ability to absorb both radial and axial (thrust) loads. This was mounted on the shaft just after the barrel and absorbed all forces caused as a result of the pressure developed at the die so that the axial force will not be impacted on the frame while the other (ball bearing) provides further support. From force analysis on the shaft, taper roller bearing receives $396 \mathrm{~N}$ and $21.36 \mathrm{kN}$ of radial and axial forces, respectively, while the radial ball bearing receives radial force of $263 \mathrm{~N}$ only. Selection of the taper roller bearing was only designed in order to determine the service life of the bearing. A $30-\mathrm{mm}$ bore diameter taper roller 
bearing of basic dynamic and static load ratings of 65 $\mathrm{kN}$ and $77 \mathrm{kN}$, respectively, with number 4T-33206 was selected [31].

Since $F_{r} / F_{a}=0.02<0.55$, the dynamic equivalent radial load for taper roller bearings under combined radial and axial or thrust loads is given by Ref. [31]:

$$
P_{a}=1.2 F_{r}+F_{a}
$$

where $F_{r}=$ radial load $(\mathrm{N}), F_{a}=$ axial or thrust load $(\mathrm{N})$, yielding $22 \mathrm{kN}$ and 17,000,000 and 1,416 of life in revolutions and hours, respectively, assuming service factor of 1 for uniform and steady load.

Table 2 shows the specifications of the major components of the extruder while Figs. 2 and 3 show the side and plan views of the fabricated extruder.

Table 2 Specification of main components of the developed extruder.

\begin{tabular}{|c|c|}
\hline Parameters & Dimension \\
\hline Length of the screw (mm) & 485 \\
\hline Length of the feed section (mm) & 143 \\
\hline Length of the compression section (mm) & 225 \\
\hline Length of the metering section (mm) & 135 \\
\hline Barrel diameter $(\mathrm{mm})$ & 40 \\
\hline Clearance between screw and barrel (mm) & 0.5 \\
\hline Compression ratio (CR) & 2.35 \\
\hline Die diameter (DD) (mm) & $3.0-7.0$ \\
\hline Shear rate $(/ \mathrm{s})$ & 139.9 \\
\hline $\mathrm{N}(\mathrm{rpm})$ & $0-200$ \\
\hline Channel width (mm) & 25 \\
\hline Pitch (mm) & 30 \\
\hline Helix angle $\left(^{\circ}\right)$ & 20 \\
\hline Theoretical mass flow rate $(\mathrm{kg} / \mathrm{h})$ & 13 \\
\hline Specific mechanical energy (SME) input $(\mathrm{kW} \cdot \mathrm{h} / \mathrm{kg})$ & 0.15 \\
\hline Cost of the extruder & 650,000 \\
\hline
\end{tabular}

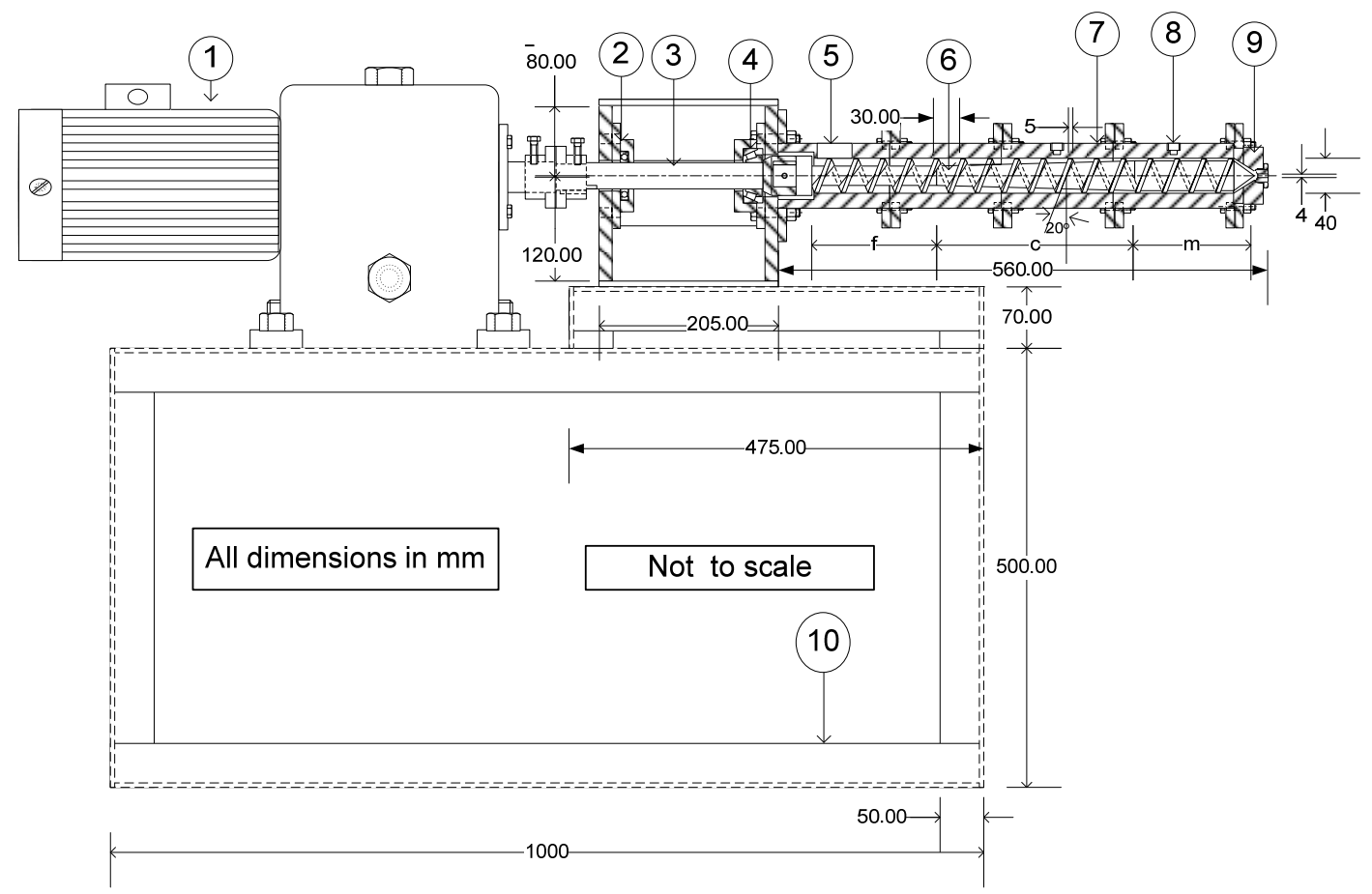

Fig. 2 Semi-sectional view of the developed laboratory extruder showing major components: (1) gear motor, (2) ball bearing, (3) shaft, (4) taper roller (thrust) bearing, (5) inlet opening that receives improvised screw feeder, (6) screw, (7) barrel, (8) thermocouple port, (9) die assembly and (10) stand. 


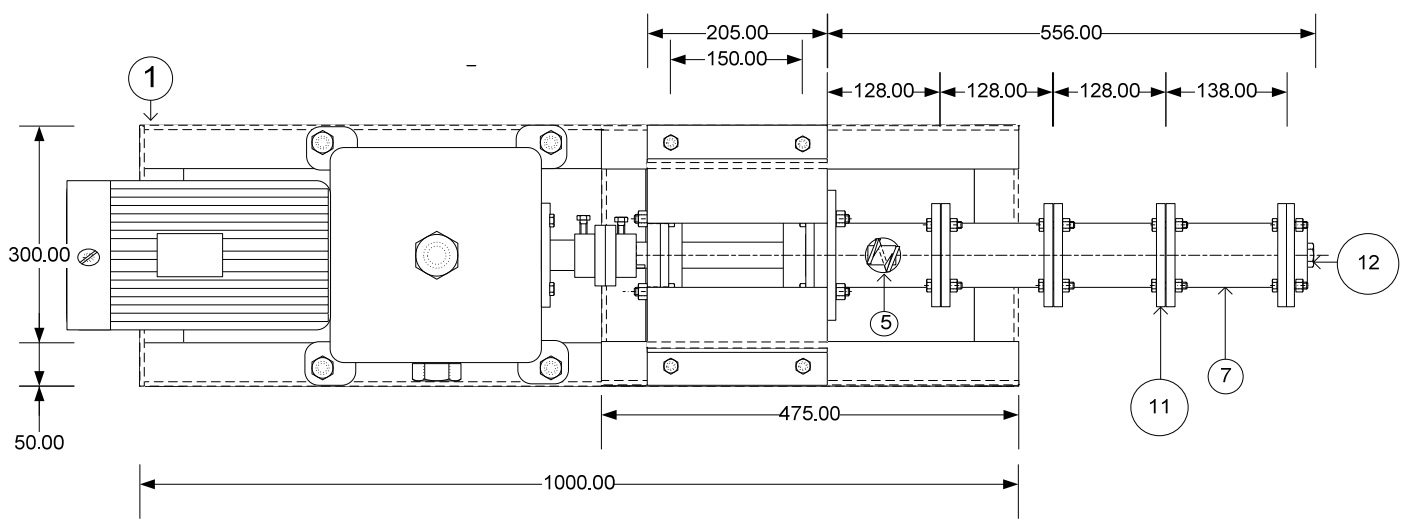

Fig. 3 Plan view of the developed laboratory extruder showing major components: (11) flange and (12) die.

\subsection{Heating, Cooling and Temperature Control}

Heating of the barrel to give the required additional thermal input and temperature control for cooking the food was done by two band heaters each having a capacity of $1 \mathrm{~kW}$ mounted on the last two barrels. Two temperature controllers were included on the control panel with their respective thermocouples sensing the temperature inside the barrels. Barrel close to the feed inlet barrel was not provided with heater to avoid premature gelatinization of the starchy materials and blockage of the feed.

\subsection{Mechanisms of Operation of the Developed Extruder}

Raw ingredients (starchy and/or proteinaceous) were pre-grounded, blended and pre-conditioned usually into a granular or flour form before being fed into the feed section by improvised screw feeder (separate design). Deep flights in this section conveyed the feed ingredients down the extruder channel. As the material moves through the transition (or compression) section to metering section, it was thoroughly worked into a dough, well cooked and elevated in temperature $\left(121-177^{\circ} \mathrm{C}\right)$ obviously due to increasing pressure and friction in this section generated because of restrictions created by increasing the root diameter from $20 \mathrm{~mm}$ to $33 \mathrm{~mm}$ spanning 225 $\mathrm{mm}$ of the screw. As the dough passes through the die (a specially designed orifice which gives the already plasticized dough a definite shape), the pressure is rapidly released, allowing a large fraction of the super-heated vapor to flash off, hence "puffing" the dough. Cooling results in thermosetting and a slight decrease in the size of the puffed dough.

Heating into a plasticized dough was achieved through a combination of the thermal energy sources generated by viscous dissipation and transferred through the barrel wall by electrical heating elements resulting in an increase in temperature and its associated phase changes (e.g., melting of solid material or evaporation of moisture). The heating element may be switched on or off depending on the attainment of preset temperatures recorded and monitored on the control panel.

\subsection{Performance Testing}

The extruder fabricated was tested on its ability to produce expanded products from blends of cassava and soybean flour. This was done by:

(1) Studying the influence of input variables on the machine performance (or system parameters), namely product temperature (PT), machine throughput (MT), RT and SME;

(2) Carrying out assessment of extrudates quality characteristics, namely product moisture (PM), ER and trypsin inhibitors reduction (TIR).

\subsubsection{Materials}

One-year-old sweet local variety of cassava (Manihot esculenta Crantz) roots popularly known as 
Okoyawo among the local farmers and processors around Ogbomoso, Nigeria and soybean were sourced from the university farm. The cassava roots were processed into flour as described by Badrie and Mellowes [32]. Whole soybean seeds were dried and partially defatted to an oil content of $8.15 \%$ using hexane as solvent and dried. Both the cassava flour (CF) and partially defatted soybean flour (PDSF) were milled by a plate attrition mill to break up lumps and made to pass through a $500 \mu \mathrm{m}$ British standard sieve and packed separately in high density polyethylene (HDPE) bags and kept frozen in a freezer until further use. All chemicals used were of analytical grade.

The chemical compositions of CF and PDSF were analyzed for moisture, crude protein $(\mathrm{N} \times 6.25)$, total fat, crude fiber and ash content using AOAC [33] standard methods 925.10, 920.87, 920.39, 925.08 and 923.03, respectively. Carbohydrate content was determined by difference $100-(\%$ moisture $+\%$ protein $+\%$ fat $+\%$ ash). At water energy conversion factors $17 \mathrm{~kJ} / \mathrm{g}(4 \mathrm{kcal} / \mathrm{g}), 37 \mathrm{~kJ} / \mathrm{g}(9 \mathrm{kcal} / \mathrm{g})$ and 17 $\mathrm{kJ} / \mathrm{g}$ (4 kcal/g) were used to calculate the energy contribution of protein, fat and carbohydrate, respectively [34]. Chemical compositions of raw material are $9.0 \%$ and $7.33 \%$ moisture, $0.27 \%$ and $8.15 \%$ crude fat, $1.95 \%$ and $46.11 \%$ protein $(\mathrm{N} \times$ 6.25 ), $2.86 \%$ and $2.19 \%$ crude fibre, $1.75 \%$ and $5.03 \%$ ash and $84.17 \%$ and $31.19 \%$ carbohydrates (by difference) for CF and PDSF, respectively.

\subsubsection{Extrusion Experiments}

The volumetric feed rate was fixed at $500 \mathrm{~cm}^{3} / \mathrm{s}$ using an improvised vertical screw dispenser (separate design). The independent variables in the experiments were: feed moisture (FM), amount of soybean (AS), barrel temperature (BT), i.e., temperature at the metering section, DD and $\mathrm{N}$, at three levels by varying one factor at a time while keeping others constant as shown in Table 3. The CF and PDSF were mixed and adjusted to predetermined moisture content levels by the addition of calculated amounts of water sprayed and admixed into each sample (w/w) according to the experimental plan (Table 3). Thereafter, each of the samples was sealed in HDPE bag and kept in a refrigerator for $24 \mathrm{~h}$ for equilibration and later brought out to room temperature for at least $8 \mathrm{~h}$ for the sample to attain room temperature. The moisture content of the blends was ascertained before extrusion by drying the samples to a constant weight in a hot air-convection oven at $105{ }^{\circ} \mathrm{C}$ [33]. Table 3 presents all the experimental runs of extrusion. Extrudates were collected, cooled and dried at $50{ }^{\circ} \mathrm{C}$ for $2 \mathrm{~d}$ and packed in HDPE bags and stored in a refrigerator at $4{ }^{\circ} \mathrm{C}$ until further analyses.

2.6.3 System Parameters

System parameters namely PT, RT, MT and SME of the cassava and soybean extrudates (CSEs) were determined following the methods of Nwabueze and Iwe [34], Oke et al. [8] and Su [35], respectively.

\subsubsection{Characterization of the Extrudates}

The CSEs obtained were characterized by defining the product in terms of moisture (\% d.b.), ER and TIR (\%) by methods of AOAC [34], Shirani and Ganesharanee [36] and Kakade et al. [37], respectively. Values obtained are as recorded in Table 3.

\section{Results and Discussion}

\subsection{Cost Estimate of the Extruder Developed}

The direct cost of fabrication of the machine was roughly $\$ 650,000.00$ or US $\$ 4,000$ at $\$ 150 /$ dollar in year 2014 when fabrication was done. The equipment was fabricated in modest local workshops at Ogbomoso and Ilorin, Nigeria. This includes the direct cost of components bought, cost of materials and parts fabricated and cost of machining and non-machining jobs performed. The machine is low cost compared with the counterpart cost of imported extruders. Even if this cost profile quadrupled to $\$ 2.0$ million (or US\$6,000 currently in 2018 at the exchange rate of \#350/dollar) it was still far cheaper than any imported machine at the lowest cost range of $£ 2,000$ as estimated by Senanayake and Clarke [16] for a 
twin-screw extruder of similar capacity. It is also much more affordable when compared to the cost of US\$20,000 required for the importation of Brabendar extruder of similar capacity.

\subsection{System Parameters}

Table 3 summarizes the overall results of the system parameters of the laboratory single-screw extruder using cassava and soybean blend samples at three different levels of each of input variables. These system parameters are measures of the system's technical performance capability and have significant effects on macromolecular degradation of biopolymers [38]. As expected, water and oil act as plasticizers in the extruder and cause a decrease in melt viscosity and mechanical energy dissipation that is friction between extruder barrel and screw walls and thus, a reduction in the PT, MT and SME, but an increase in RT [39]. Similar reports have been made about rising $\mathrm{PT}$ in the extrusion of starchy raw materials [40, 41]. It is evident that the extruder performed satisfactorily in raising the PT $\left(121-175^{\circ} \mathrm{C}\right)$ and held the food melt for RT between $49.67 \mathrm{~s}$ and $72.11 \mathrm{~s}$ which are adequate enough in changing the rheological properties of extruded melts, and in turn affect the degree of expansion of starchy materials
[41].

SME encompasses extruder system parameters such as $\mathrm{N}$, amperage/torque and MT in its calculation [35]. High SME was observed at lower BT, FM, DD and N. These input parameters at low levels offer higher resistance to MT and cause the extruder to draw higher power. Oke et al. [8] and Chevanan et al. [42] reported similar findings. At low BT and FM, there was need for more mechanical power inputs to overcome resistance offered against material transport coupled with the likely higher die pressure of extrusion as indicated in Eq. (5). The values of SME as recorded in Table 3 validate the fact that the extruder performed to its billing as an energy efficient process.

\subsection{Extrudate Characteristics}

The moisture contents of CSEs ranged between 8.88 (\% d.b.) and 13.33 (\% d.b.) as recorded in Table 3 , indicating acceptable moisture levels that would enhance the shelf-stability of the extrudates. These values fall within the range reported for rice/legume blends by Asare et al. [43]. This indicated ability of the extruder to produce shelf-stable products that will be safe for an extended period of time if well packaged. Expansion is an important characteristic of

Table 3 Effects of extrusion conditions on product characteristics and system parameters ${ }^{\mathrm{a}}$.

\begin{tabular}{|c|c|c|c|c|c|c|c|c|c|c|c|c|}
\hline \multirow{2}{*}{ Run no. } & \multicolumn{5}{|c|}{ Input variables ${ }^{\mathrm{b}}$} & \multicolumn{4}{|c|}{ System parameters $^{\mathrm{c}}$} & \multicolumn{3}{|c|}{ Extrudate characteristics ${ }^{\mathrm{d}}$} \\
\hline & FM & AS & BT & DD & $\mathrm{N}$ & PT & RT & MT & SME & PM & ER & TIR \\
\hline 1 & 16 & 20 & 145 & 5 & 180 & 150 & 49.67 & 10.42 & 0.0623 & 8.88 & 2.98 & 63.14 \\
\hline 2 & 20 & 20 & 145 & 5 & 180 & 147 & 57.68 & 9.16 & 0.0532 & 9.67 & 2.69 & 72.95 \\
\hline 3 & 24 & 20 & 145 & 5 & 180 & 145 & 60.95 & 8.68 & 0.0521 & 13.13 & 2.43 & 83.77 \\
\hline 4 & 20 & 10 & 145 & 5 & 180 & 148 & 50.10 & 9.42 & 0.0503 & 10.11 & 2.75 & 67.82 \\
\hline 5 & 20 & 30 & 145 & 5 & 180 & 145 & 68.15 & 9.01 & 0.0480 & 9.28 & 2.53 & 69.34 \\
\hline 6 & 20 & 20 & 120 & 5 & 180 & 121 & 53.73 & 10.79 & 0.0588 & 11.71 & 2.14 & 65.34 \\
\hline 7 & 20 & 20 & 170 & 5 & 180 & 175 & 68.12 & 8.95 & 0.0447 & 9.20 & 2.74 & 87.93 \\
\hline 8 & 20 & 20 & 145 & 4 & 180 & 161 & 72.11 & 8.86 & 0.0676 & 9.11 & 2.72 & 79.31 \\
\hline 9 & 20 & 20 & 145 & 6 & 180 & 141 & 52.34 & 10.35 & 0.0456 & 12.07 & 1.82 & 61.07 \\
\hline 10 & 20 & 20 & 145 & 5 & 160 & 155 & 70.43 & 8.87 & 0.0542 & 9.34 & 2.68 & 80.11 \\
\hline 11 & 20 & 20 & 145 & 5 & 200 & 148 & 57.38 & 11.17 & 0.0649 & 11.97 & 1.95 & 63.21 \\
\hline
\end{tabular}

${ }^{\mathrm{a}}$ All data presented are average of duplicate; ${ }^{b} \mathrm{FM}\left(\mathrm{g}\right.$ water/100 g), AS: amount of soybean $(\mathrm{g}$ soybean $/ 100 \mathrm{~g}), \mathrm{BT}\left({ }^{\circ} \mathrm{C}\right), \mathrm{DD}(\mathrm{mm}), \mathrm{N}$ $(\mathrm{rpm}) ;{ }^{\mathrm{c}} \mathrm{PT}\left({ }^{\circ} \mathrm{C}\right), \mathrm{RT}$ : residence time (s), MT: machine throughput $(\mathrm{kg} / \mathrm{h}), \mathrm{SME}(\mathrm{kJ} / \mathrm{kg})$; ${ }^{\mathrm{d}} \mathrm{PM}$ : product moisture $(\%)$, TIR: trypsin inhibitors reduction (\%). 
extrudates intended as snack and ready-to-eat products by the food industries. ER describes the degree of puffing undergone by the melt as it exits the extruder die as extrudates [44]. All treatments resulted in a reasonable degree of expansion (1.82-2.98) as recorded in Table 3. Although the ER decreased as the concentration of FM, AS and BT increased (Table 3), it can be inferred that the machine performed fairly well as a medium-to-high shear extruder that can be used in the production of snacks, ready-to-eat cereals, pet foods, fish flour, fingers, etc.

Low anti-trypsin activity was recorded for extrudates under all experimental conditions especially at low levels of all the input variables, which indicated that high temperature and high mechanical stress developed during extrusion processing inactivated substances responsible for these factors. Reported reduction values after the extrusion of beans [45] have usually been 95\%, at extrusion temperature range of $120-150{ }^{\circ} \mathrm{C}$, which was also achieved with the extruder developed, though at higher temperature. Temperatures recorded in these experiments reached $175{ }^{\circ} \mathrm{C}$, which was more severe and destroyed the trypsin inhibitors to the expected level. Despite the high thermal stability of trypsin inhibitors, the combination of high heat and high humidity in the extrusion process considerably reduced their inhibitory activity in the CSEs (61.07\%-87.93\%) as shown in Table 3. These results confirm those recorded by Alonso et al. [46] and Anton et al. [47].

\section{Conclusions}

A laboratory extruder was designed and fabricated from engineering materials that are easily sourced locally at a low cost. The unit was tested and found capable of producing expanded extrudates from cassava-soy blends at a mass throughput very close to theoretical value at reasonably low energy cost typical of extrusion processing although with some heating from band heaters mounted on the barrels. Control devices to vary machine four variables apart from feed variables to satisfy multivariable criteria of extrusion process were provided on the control panel. Being made in Nigeria conjures up many economic and technical benefits for this machine especially by its ethos of promoting self-reliance. Therefore, the extruder is considered to be relevant for technological environment of DCs of which Nigeria is a typical example. The simple laboratory scale single-screw extruder workstation is capable of opening up a new vista in product and research development in the country where there is vast supply of bio-resources that are begging to be exploited to meet nutritional needs of the populace and/or in times of emergencies.

\section{Acknowledgments}

The effort of Mr. Idowu Oke of Electronics and Electrical Engineering Department, LAUTECH, Ogbomoso, is highly appreciated by the authors for development of control systems for this project with no monetary gain.

This research did not receive any specific grant from funding agencies in the public, commercial, or not-for-profit sectors.

\section{References}

[1] Milan-Carrillo, J., Reyes-Moreno, J., Camacho-Hernandez, C., and Rouzaud-Sandez, O. 2002. "Optimisation of Extrusion Process to Transform Hardened Chickpeas (Cicer arietinum L.) into a Useful Product." Journal of Science for Food and Agriculture 82: 1718-28. https://doi.org/10.1002/jsfa.1242.

[2] Riaz, M. N. 2000. Extruders in Food Applications. Boca Raton, FL: CRC Press.

[3] Filli, K. B., Nkama, I., Abubakar, U. M., and Jideani, V. A. 2010. "Influence of Extrusion Variables on Some Functional Properties of Extruded Millet-Soybean for the Manufacture of Fura: A Nigerian Traditional Food." African Journal of Food Science 4 (6): 342-52. doi: 10.12691/jfnr-2-5-7.

[4] Iwe, M. O., van Zuilichem, D. J., Stolp, W., and Ngoddy, P. O. 2004. "Effect of Extrusion Cooking of Soy-Sweet Potato Mixtures on Available Lysine Content and Browning Index of Extrudates." Journal of Food Engineering $\quad 62: \quad 143-50$. 
https://doi.org/10.1016/S0260-8774(03)00212-7.

[5] Nkama, I., and Filli, K. B. 2006. "Development and Characteristics of Extruded Fura from Mixtures of Pearl Millet and Grain Legumes Flours." International Journal of Food Properties 9: 1-9.

[6] Nwabueze, T. U., and Iwe, M. O. 2006. "Mass Flow Rate, Nutrient Composition and Some Functional Properties of Single-Screw Extruded Africa Breadfruit (Treculia africana) Blends." Journal of Food Technology 4: 50-8. http://medwelljournals.com/abstract/?doi=jftech.2006.50. 58.

[7] Obatolu, V. A. 2002. "Nutrient and Sensory Qualities of Extruded Malted or Unmalted Millet/Soybean Mixture." Journal of Food Chemistry 76: 129-33. doi: 10.1016/s0308-8146(01)00188-1.

[8] Oke, M. O., Awonorin, S. O., Sanni, L. O., Asiedu, R., and Aiyedun, P. O. 2013. "Effect of Extrusion Variables on Extrudates Properties of Water Yam Flour-A Response Surface Analysis.” Journal of Food Processing and Preservation 37: 456-73. https://doi.org/10.1111/j.1745-4549.2011.00661.x.

[9] Oluwole, O. B., Awonorin, S. O., Henshaw, F., Elemo, G. N., and Ebuehi, O. A. T. 2013. "Assessment of Microbial Changes and Nutritional Qualities of Extruded White Yam (Dioscorea rotundata) and Bambara Groundnut (Vigna subterranean) Blends." Food and Nutrition Science 4: 100-7. doi: 10.4236/fns.2013.41014.

[10] Harper, J. M. 1981. Extrusion of Foods. Vol. I and II. Boca Raton, Florida: CRC Press.

[11] Mouquet, C., Salvingnol, B., van Hoan, N., Monvois, J., and Treche, S. 2003. "Ability of a 'Very Low-Cost Extruder' to Produce Instant Flours at a Small Scale in Vietnam." Journal of Food Chemistry 82: 249-55. https://doi.org/10.1016/S0308-8146(02)00545-9.

[12] Harper, J. M., and Jansen, G. R. 1985. "Production of Nutritious Precooked Foods in Developing Countries by Low-Cost Extrusion Technology." Food Review International 1: 27-97.

[13] Ilo, S., and Berghoper, E. 2003. "Kinetics of Lysine and Other Amino Acids Loss during Extrusion Cooking of Maize Grits." Journal of Food Science 68: 496-501. https://doi.org/10.1111/j.1365-2621.2003.tb05701.x.

[14] Filli, K. B., Nkama, I., and Jideani, V. A. 2013. "The Effect of Extrusion Conditions on the Physical and Functional Properties of Millet-Bambara Groundnut Based Fura." American Journal of Food Science and Technology 1 (4): 87-101.

[15] van Zuilichem, D. J., Stolp, W., and Janssen, L. B. P. 1984. "Engineering Aspects of Single and Twin Screw Extrusion Cooking of Bio-polymers." In Extrusion Cooking Technology, edited by Jowett, R. Amsterdam: Elsevier. https://doi.org/10.1016/0260-8774(83)90008-0.
[16] Senanayake, S. A. M. A. N. S., and Clarke, B. 1999. "A Simplified Twin Screw Co-rotating Food Extruder: Design, Fabrication and Testing." Journal of Food Engineering 40: 129-37. https://doi.org/10.1016/S0260-8774(99)00049-7.

[17] Harmann, D. V., and Harper, J. M. 1974. "Modeling a Forming Extruder.” Journal of Food Science 39: 1099-104. https://doi.org/10.1111/j.1365-2621.1974.tb07326.x.

[18] Rauwendaal, C. 2001. Polymer Extrusion. Munichen: Carl Hanser Verlag.

[19] Tadmor, A., and Klein, I. 1970. Engineering Principles of Plasticating Extrusion. New York: Van Nostrand Reinhold Company.

[20] Hauck, B. W. 1993. "Choosing an Extruder." In Food Technology International Europe, edited by Turner, A. London: Sterling Publications Int., 81-2.

[21] Rossen, J. L., and Miller, R. C. 1973. "Food Extrusion." Food Technology 27 (8): 46-53.

[22] Dziezak, J. D. 1989. "Single- and Twin-Screw Extruders in Food Processing." Food Technology 44 (4): 164-74.

[23] Singh, J., and Bargale, P. C. 2000. "Development of a Small Capacity Double Stage Compression Screw Press for Oil Expression." Journal of Food Engineering 43: 75-82.

[24] Khurmi, R. S., and Gupta, J. K. 2012. A Textbook of Machine Design. New Delhi: Eurasia Publishing House Limited.

[25] Harper, J. M. 1979. "Food Extrusion." Crit. Review in Food Science and Nutrition 11: 155-215. https://doi.org/10.1080/10408397909527262.

[26] Janssen, L. P. B. M., and Moscicki, L. 2010. "Design and Modeling of a Single-Screw Extruders.” TEKA Kom Mot. Energ. Roln. OL PAN 10: 136-44.

[27] Fraiha, M., Biagi, J. D., and Ferraz, J. C. D. 2011. "Rheological Behavior of Corn and Soy Mix as Feed Ingredients." Ciencia e Tecnologia de Alimentos 31 (1): 129-34.

[28] Sokhey, A. S., Ali, Y., and Hannab, M. A. 1997. "Effects of Die Dimensions on Extruder Performance." Journal of Food Engineering 31: 251-61.

[29] Chinnaswamy, R., and Hanna, M. A. 1987. "Nozzle Dimension Effects on the Expansion of Extrusion Cooked Corn Starch." Journal of Food Science 52: 1746-7. https://doi.org/10.1111/j.1365-2621.1987.tb05924.x.

[30] Spotts, M. F. 1971. Design of Machine Elements, 4th ed. Englewood Cliffs, NJ: Prentice Hall Inc.

[31] NTN CAT. NO. 2202-IX/.E. 2009. Ball and Roller Bearings Catalogue. NTN Corporation, A17-20.

[32] Badrie, N., and Mellowes, W. A. 1991. "Effect of Extrusion Variables on Cassava Extrudates." Journal of Food Science 56: 1334-7. doi: 10.1111/j.1365-2621.1991.tb04766.x. 
[33] AOAC. 1995. Official Methods of Analysis of the Association of Official Analytical Chemists, 15th edition. Washington, DC.

[34] Nwabueze, T. U., and Iwe, M. O. 2006. "Mass Flow Rate, Nutrient Composition and Some Functional Properties of Single Screw Extruded Africa Breadfruit (Treculia africana) Blends." J. Food Technol. 4 (1): 50-8.

[35] Su, C. 2007. "Effects of Eggshell Powder Addition on the Extrusion Behaviour of Rice." Journal of Food Engineering 79: 607-12.

[36] Shirani, G., and Ganesharanee, R. 2009. "Extruded Products with Fenugreek (Trigonella foenum-graecium) Chickpea and Rice: Physical Properties, Sensory Acceptability and Glycaemic Index." Journal of Food Engineering 90: 44-52.

[37] Kakade, M., Rackis, J., McGhee, J., and Puski, G. 1974. "Determination of Trypsin Inhibitor Activity of Soy Products: A Collaborative Analysis of an Improved Procedure." Cereal Chemistry 51: 376-82.

[38] Lazou, A. A., and Krokida, M. 2010. "Structural and Textural Characterization of Corn-Lentil Extruded Snacks." Journal of Food Engineering 100: 392-408. https://doi.org/10.1016/j.jfoodeng.2010.04.024.

[39] Ilo, S., Tomschik, U., Berghofer, E., and Mundigler, N. 1996. "The Effect of Extrusion Operating Conditions on the Apparent Viscosity and the Properties of Extrudates in Twin-Screw Extrusion Cooking of Maize Grits." LWT-Food Science and Technology 29 (7): 593-8. https://doi.org/10.1006/fstl.1996.0092.

[40] Jin, Z., Hsieh, F., and Huff, H. E. 1994. "Extrusion of Corn Meal with Soy Fiber, Salt, and Sugar." Cereal Chemistry 71: 227-34.

[41] Meng, X., Threinen, D., Hansen, M., and Driedger, D. 2010. "Effects of Extrusion Conditions on System
Parameters and Physical Properties of a Chickpea Flour-Based Snack." Food Research International 43: 650-8. https://doi.org/10.1016/j.foodres.2009.07.016.

[42] Chevanan, N., Muthukumarappan, K., and Rosentrater, K. A. 2007. "Neural Network and Regression Modeling of Extrusion Processing Parameters and Properties of Extrudates Containing DDGS." Transactions of the ASABE 50: 1765-78. doi: 10.13031/2013.23934.

[43] Asare, E. K., Sefa-Dedeh, S., Sakyi-Dawson, E., and Afoakwa, E. O. 2004. "Application of Response Surface Methodology for Studying the Product Characteristics of Extruded Rice-Cowpea-Groundnut Blends." International Journal of Food Science and Nutrition 55: 431-9. http://dx. doi:10.1016/j.foodres.2009.09.033.

[44] Baladran-Quintana, R. R., Barbosa-Canovas, G. V., Zazueta-Morales, J. J., Anzaldua-Morales, A., and Quintero-Ramos, A. 1998. "Functional and Nutritional Properties of Extruded Whole Pinto Bean Flour (Phaseolus vulgaris L.)." Journal of Food Science 63: 113-6. doi:10.1111/j.1365-2621.1998.tb15688.x.

[45] Noguchi, A. 1986. Food Processing Activities in Japan on the Use of Twin-Screw Extruders. Report of the National Food Research Institute, Tsukuba, Japan, 40.

[46] Alonso, R., Aguirre, A., and Marzo, F. 2000. "Effects of Extrusion and Traditional Processing Methods on Antinutrients and in Vitro Digestibility of Protein and Starch in Faba and Kidney Beans." Food Chem. 68: 159-65.

[47] Anton, A. A., Fulcher, R. G., and Arntfield, S. D. 2009. "Physical and Nutritional Impact of Fortification of Corn Starch Based Extruded Snacks with Common Bean (Phaseolus vulgaris L.) Flour: Effects of Bean Addition and Extrusion Cooking." Food Chemistry 113: 989-96. https://doi.org/10.1016/j.foodchem.2008.08.050. 